\title{
Zed's fanverse
}

It's only a game...

\section{Toiya Kristen Finley}

Brad promised it wasn't a timesuck, but Dustin knew he shouldn't have trusted a man who succumbed to EverCrack. GloriousCivilization, still in open beta, wasn't like EverQuest though. The promise of a "Part Online RPG, Part Social Experiment", with medieval world (Az) and cyberpunk future (Zed) to choose from. Superior AI. Avatars with evolving personalities, even when their human players weren't logged in. And intelligent non-player characters? Dustin wasn't completely sold, but the game was free.

Dustin chose Az and a female field nymph. Nymphs lacked the pointyeared pretentiousness of the ubiquitous elves. He trawled through the psychological character profile -200 multiple-choice questions ranging from favourite food to preferred killing methods - and created a shaman. Amethyst skin, faint blue hair, with eyes the colour of deep honey. Her long wings wrapped around her chest as protection. In his teenaged days, he would have given Etérea enormous breasts. But hers were small, attractive bumps under the filaments of her wings.

When Dustin logged onto Az for the first time, Etérea greeted him in her bungalow along with three others.

"Good morning, Dustin. Please meet my friends." The light accent, perhaps Hungarian, and her boldness in addressing him startled Dustin, as did her happiness at the presence of the avatars in her room. It soon became clear by their conversation that the centaur paladin, human priest and elf rogue were not with their human companions. Dustin wasn't sure whether he was fascinated or horrified.

He wasted the greater part of his afternoon watching the four on a quest for a lost goblet. At the appearance of hostile NPCs and evil creatures, Etérea asked him what attacks she should use. Dustin left that up to her. She was marvellous without him.

"I left for an hour, and he'd already levelled up by the time I got back."

Dustin had no time for chatting with Brad, let alone his avatar. But here they both were, irritating with their giggling over IM. Ivan Glaiveman, a wiry, brunette hacker was just as big a dork as Brad. Brad thinking it cool to dress him in a basketball jersey under a trench coat, jeans, hiking boots and gloves with the fingers cut out.
"Glaive took me to this hopping club last night. Dusty, the girls were insane."

"Ditch Az", the avatar said.

"I don't have time for Zed, let alone Az. Some of us have deadlines."

"Carpe diem, desk jockey! Stick it to the man!”

Dustin wished Etérea were there to smack Glaiveman with her staff.

"You must be bored with that slut in pointless old Az."

Dustin never mentioned Etérea to Brad. "Ivan, what do you know?"

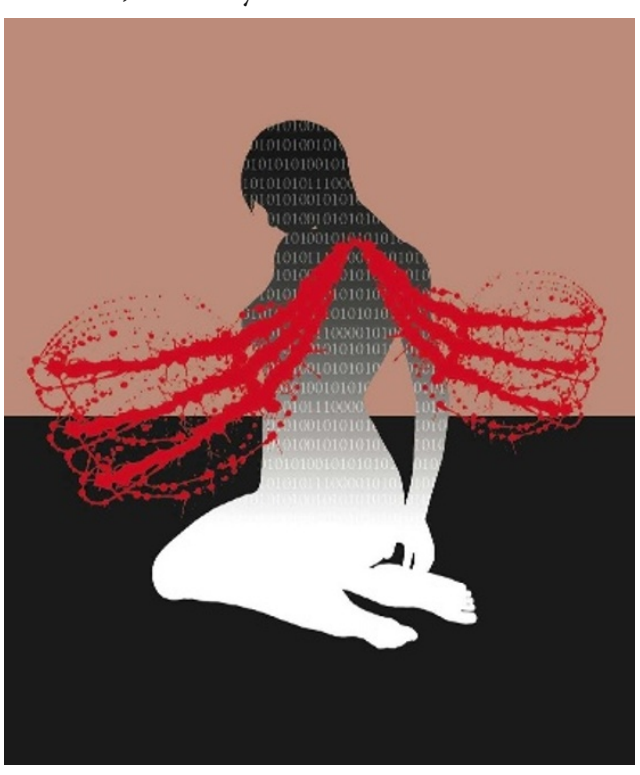

"Everybody knows what goes down in Az." Glaiveman grinned a series of goldcapped teeth. What had Brad answered for his psych profile?

"You should defend your little fanverse on the boards," Brad said. "Everybody's torching Az."

Dustin was determined not to let GloriousCiv become a timesuck, but he did scan the message boards, only because he despised Glaiveman. He had his argument planned: Zed featured nothing but humans; an uninspiring future without alien races, or even mutants. Zed's setting was too close to the present, whereas diverse creatures in a distant past with the present's societal values made for a more interesting experiment. But, after reading thread after thread of "AZ SUXORZ," and wincing at the vitriol against Az's fanverse, Dustin didn't bother.

He hadn't logged on in a while, but Dustin knew she'd understand work came first. He didn't find Etérea in her bungalow, but in Alsden Cave cowering behind a stalagmite, the bodies of her centaur and human friends in front of her.

"Etérea?"

"I couldn't heal them." She didn't look up. "What happened?"

Ivan leapt from behind a boulder and grinned. "Etérea's changing addresses." He grabbed her hand. Dustin saw the tattered holes in the wings draped around her shoulders. She still couldn't look at him.

"You're taking her to Zed?"

"Yup, and Dusty? There's this fine piece in Finland who likes rubies. Thanks to Etérea, Noora'll be getting a bracelet from her favourite hacker soon."

Dustin slammed his palm against the desk, realizing Etérea had divulged his financial information. "How could you?"

She glanced at him. "I didn't want to die... You never...”

Ivan Glaiveman dragged her out of the cave into a cloudy day. Humans in trench coats and boots, short skirts and sneakers, and double-breasted suits rampaged Alsden's countryside. Machinists riding metal monsters prodded the beasts to plough square teeth into hills, trees and houses.

Amid the death of Az, Ivan and Etérea stepped into a portal of light and disappeared.

Brad apologized for Glaiveman's behaviour, but he did nothing to stop Ivan, or his own growing popularity in Zed and networks beyond. Glaiveman let Dustin see Etérea a couple of times, her hair and skin colour changed, before blocking him from Zed's server. She, like so many Az avatars, became the property of Zed's fanverse, the characters remade, recoded, used as slaves and shields in battle.

GloriousCiv's programmers scrambled to get Zed under control, but that wasn't easy when virtual hackers had access to the code. Members of Az suffered viral attacks and frequent outages.

When Glaiveman crashed his hard drive again, Dustin wondered how Az could have been so weak, how his creation of a strong, liberated female could fall prey to a punk like Glaiveman. When his lights snapped off under Zed's wrath, Dustin wondered if he were perfectly suited to $\mathrm{Az}$ and resigned himself to Etérea's fate, a desk jockey begging for survival all along.

Toiya Kristen Finley is a former professional student and freelancer. She is a fictionist, creative essayist and sometime academic. 